University of Nebraska - Lincoln

DigitalCommons@University of Nebraska - Lincoln

Faculty Publications from the Harold W. Manter Laboratory of Parasitology

1995

\title{
Silver Staining for Elucidation of the Synlophe in Trichostrongyle Nematodes
}

Alexander V. Khrustalev

K. I. Skrjabin Institute of Helminthology

Eric P. Hoberg

USDA-ARS, eric.hoberg@ars.usda.gov

Follow this and additional works at: https://digitalcommons.unl.edu/parasitologyfacpubs

Part of the Parasitology Commons

Khrustalev, Alexander V. and Hoberg, Eric P., "Silver Staining for Elucidation of the Synlophe in Trichostrongyle Nematodes" (1995). Faculty Publications from the Harold W. Manter Laboratory of Parasitology. 727.

https://digitalcommons.unl.edu/parasitologyfacpubs/727

This Article is brought to you for free and open access by the Parasitology, Harold W. Manter Laboratory of at DigitalCommons@University of Nebraska - Lincoln. It has been accepted for inclusion in Faculty Publications from the Harold W. Manter Laboratory of Parasitology by an authorized administrator of DigitalCommons@University of Nebraska - Lincoln. 


\section{Silver Staining for Elucidation of the Synlophe in Trichostrongyle Nematodes}

Alexander V. Khrustalev and Eric P. Hoberg, ${ }^{\star}$ K. I. Skrjabin Institute of Helminthology, Central Helminthological Museum, Bol'shaya Cheryomushinskaya 28, 117259 Moscow, M-259, Russia; *Biosystematics and National Parasite Collection Unit, USDA, Agricultural Research Service, BARC East Building 1180, 10300 Baltimore Avenue, Beltsville, Maryland 20705-2350

\begin{abstract}
Staining techniques are relatively rare in the study of parasitic nematodes. A novel silver-staining method is described for elucidation of the synlophe (a system of longitudinal cuticular ridges), a character of great systematic importance among the trichostrongyloid nematodes. Ridges are stained optically black and appear in great contrast to the body of the nematode. This method augments current use of interference contrast for examination of the synlophe. Detailed studies of the configuration of the synlophe in entire specimens are possible with standard light microscopy for the first time.
\end{abstract}

The synlophe, a system of longitudinal cuticular ridges, is a characteristic structure among the trichostrongyloid nematodes (equivalent to the suborder Trichostrongylina of Durette-Desset and Chabaud [1993]). Application of the synlophe as a morphological character in systematics was introduced by DuretteDesset (1964) in research on heligmosome nematodes and later refined in exhaustive studies among families of the Trichostrongyloidea (see Durette-Desset, 1985). These studies were based principally on evaluation of transverse sections, concentrating on enumeration, structure, relative dimensions, height, and orientation of ridges in the midbody region (Durette-Desset, 1983). This basic approach was modified by Lichtenfels (1977) for species of Cooperia Ransom, 1907 and later other trichostrongylids. The synoptic method detailed traditional characters but also emphasized the specific patterns of ridges ventrally and laterally in the cervical zone (anterior to the base of the esophagus), and their posteriad extent in males and females (Lichtenfels and Pilitt, 1983; Lichtenfels et al., 1988). Documentation of these characters has become standard practice in taxonomy and systematics of the Ostertagiinae and related nematodes of the family Trichostrongylidae (see Hoberg et al., 1993; Hoberg and Lichtenfels, 1994).

Although the configuration and pattern of the synlophe, particularly in the cervical region, could be studied in whole-mounted nematodes with standard transmitted light microscopy, fine details of structure were often obscure. Consequently, differential interference-contrast and scanning electron microscopy have commonly been used to elucidate the synlophe in entire specimens. However, these later methods often are not readily available in many laboratories. In the present report, we provide a simple, reliable, and rapid technique for staining of the syn-

* To whom correspondence should be addressed. lophe, which augments and may replace the use of interferencecontrast optics.

Stains have not been in general use for studies of nematodes (see Pritchard and Kruse, 1982), although there have been some specialized applications (Hooper, 1986). Where silver stains have been applied in comparative morphology, they have been used to differentiate internal and neural tissues (Croll and Maggenti, 1968) and some cuticular attributes in freeliving and plantparasitic nematodes (Bedding, 1968; Rodriguez-Kabana and King, 1976). Additionally silver nitrate staining has been used to augment examination of sensory structures with scanning electron microscopy (Vanderburgh et al., 1987). In the present paper we describe a technique in which a silver stain is used specifically to enhance definition of the synlophe in entire specimens of trichostrongylid nematodes.

Intact specimens may be processed from solutions of buffered $10 \%$ formalin, $70 \%$ ethanol, alcohol-formalin-acetic acid, and other preservatives or fixatives. Specimens must first be hydrated, then are passed through a series of reagents. The process for a typical ostertagiine nematode, e.g., Camelostrongylus mentulatus (Railliet and Henry, 1909) is as follows at approximately $20 \mathrm{C}$ : (1) wash in distilled $\mathrm{H}_{2} \mathrm{O}$; (2) incubate in $1.0 \%$ solution of $\mathrm{NaCl}$ for a minimum of $15 \mathrm{~min}$; (3) stain in $0.2 \%$ solution

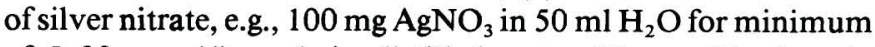
of 5-30 sec; (4) wash in distilled water $30 \mathrm{sec}$; (5) place in photographic developer, e.g., Dektol diluted at $4 \mathrm{H}_{2} \mathrm{O}$ : 1 stock solution, for 5-20 sec; (6) wash in distilled water 1-2 sec; (7) differentiate in photographic fixative for $30 \mathrm{sec}$; and (8) wash in distilled water $10 \mathrm{sec}$ prior to mounting. Commonly used mounting media include water, lactophenol, or phenol alcohol. Following rehydration, the stain can be removed by using an aqueous solution of $1 \%$ potassium cyanoferrate $\left(\mathrm{K}_{3} \mathrm{Fe}[\mathrm{CN}]_{6}\right)$, and the specimens can then be returned to fixative.

The timing of periods for washes and retention in each of the reagents are variable; fresh reagents should be prepared daily. It is requisite that specimens be retained in $\mathrm{NaCl}$ for a minimum of $15 \mathrm{~min}$, because the presence of chloride ions is essential for reactions that result in the deposition of silver on the cuticle of the nematode. Small specimens, e.g., males among species of Ostertagia Ransom, 1907, may be passed through silver nitrate and fixative for a maximum of 5-10 sec, whereas some larger specimens, e.g., species of Haemonchus Cobb, 1898 and $\mathrm{Ne}$ matodirus Ransom, 1907, may require a longer period for max-

FIGURES 1-9. A comparison of the synlophe in specimens of Camelostrongylus mentulatus and Ostertagia ostertagi, as observed with light microscopy (LM; Figs. 1 and 4), interference-contrast microscopy (IC; Figs. 2 and 5), and silver staining (S; Figs. 3, 6-9). Scale bars $=25 \mu \mathrm{m}$ for Figures 1-8 with same scale bars for Figures 1-6, 7, and 8; $50 \mu \mathrm{m}$ for Figure 9. 1-3. Cephalic region of $C$. mentulatus in lateral view showing termination of synlophe (pointers) in LM (Fig. 1), IC (Fig. 2), and with S (Fig 3). 4, 5. Cervical zone of $C$. mentulatus in lateral view near level of cervical papilla in LM (Fig. 4), IC (Fig. 5), and S (Fig. 6). 7-9. Synlophe in O. ostertagi in specimen prepared with silver stain, showing lateral view of posterior cervical region (Fig. 7); lateral view of region anterior to copulatory bursa in male (Fig. 8); and lateral view of copulatory bursa showing pattern of termination of ridges in the ventral field (Fig. 9). 

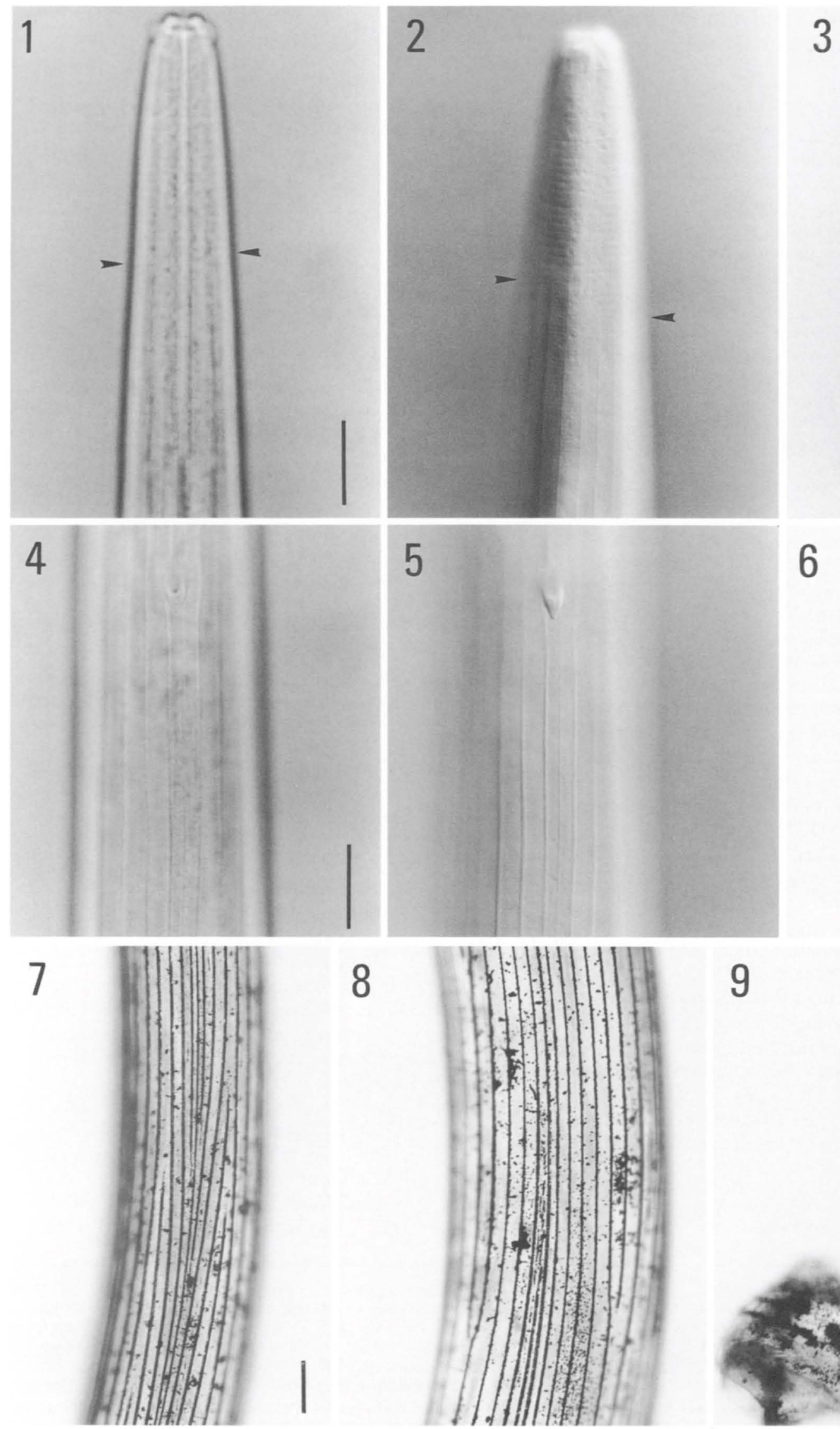

8
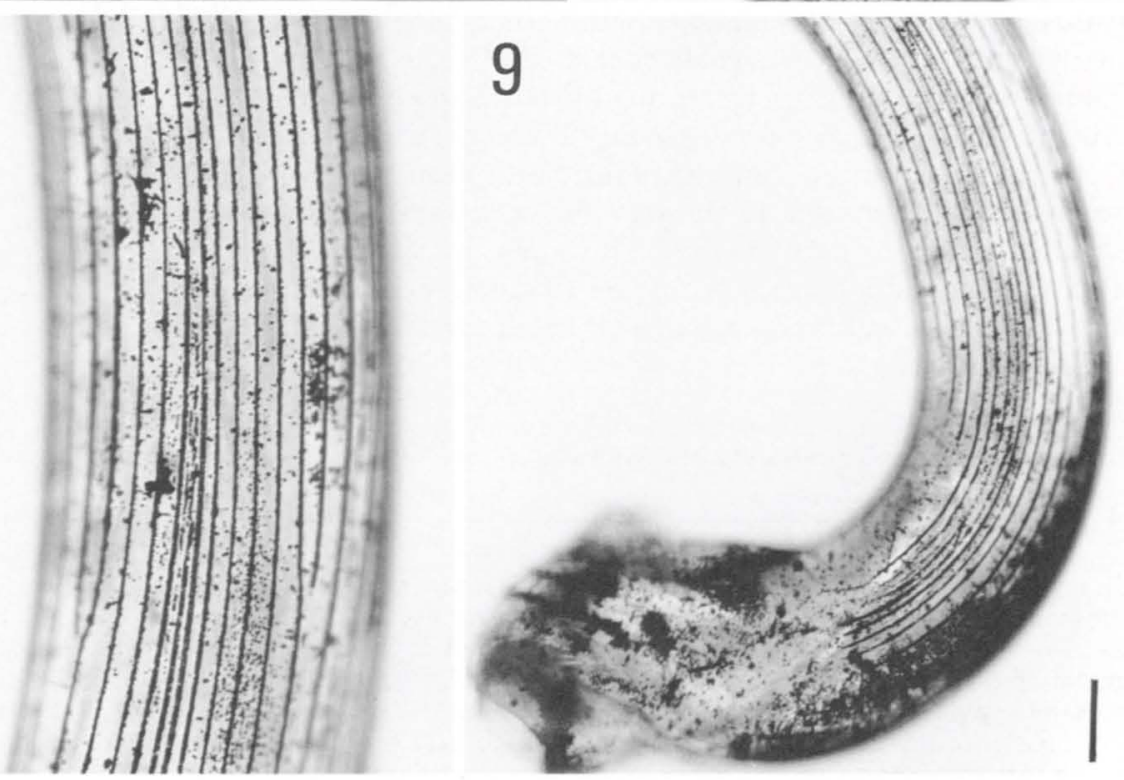
imum staining. Optimum results are achieved with careful attention to the concentration of $\mathrm{NaCl}$ and $\mathrm{AgNO}_{3}$ and the duration of exposure in these reagents.

The ridges in specimens prepared in this manner are optically black and appear in great contrast to the body of the nematode as shown in specimens of $C$. mentulatus and Ostertagia ostertagi (Stiles, 1892) (Figs. 1-9). The transverse striations, typical of many trichostrongyles, are also strongly highlighted. This technique is particularly useful for examining ridges near their anterior termination at the base of the cephalic expansion (Figs. 1-3) and for patterns in the cervical zone (Figs. 4-7). The entire synlophe is stained, promoting detailed examination of the posteriad extent of the ridges in males and females (Figs. 8, 9). Characters may be revealed with this method that are otherwise difficult to observe using either standard or interference-contrast light microscopy and as such will substantially augment the study of the synlophe in entire specimens as currently practiced.

\section{LITERATURE CITED}

BEDDING, R. A. 1968. A technique for displaying the surface structure of nematodes. Nematologica 13: 643 .

Croll, N. A., AND A. R. MAGgenti. 1968. A peripheral nervous system in Nematoda with a discussion of its functional and phylogenetic significance. Proceedings of the Helminthological Society of Washington 35: 108-115.

DurETte-DESSET, M. C. 1964. Les systémes d'arêtes cuticulaires chez Nematodes Héligmosomes. Étude de cinq espèces parasites de rongeurs de la Maboke. Cahiers Maboké 2: 39-78.

- 1983. Keys to the genera of the superfamily Trichostrongyloidea. No. 10. In $\mathrm{CIH}$ keys to the nematode parasites of vertebrates, R. C. Anderson and A. G. Chabaud (eds.) Commonwealth Agricultural Bureaux, Farnham Royal, U.K., p. 1-86.

1985. Trichostrongyloid nematodes and their vertebrate hosts:
Reconstruction of the phylogeny of a parasitic group. Advances in Parasitology 24: 239-306.

- AND A. G. Chabaud. 1993. Nomenclature des Strongylida au-dessus du groupe-famille. Annales de Parasitologie Humaine et Comparée 68: 111-112.

Hoberg, E. P., AND J. R. Lichtenfels. 1994. Phylogenetic systematic analysis of the Trichostrongylidae (Nematoda), with an initial assessment of coevolution and biogeography. Journal of Parasitology 80: 976-996.

,-- AND P. A. PILITT. 1993. Comparative morphology of Ostertagia mossi and Ostertagia dikmansi (Trichostrongylidae) from Odocoileus virginianus and comments on other Ostertagia spp. from the Cervidae. Systematic Parasitology 24: 111-127.

HOOPER, D. J. 1986. Handling, fixing, staining and mounting nematodes. In Laboratory methods for work with plant and soil nematodes, J. F. Southey (ed.) H.M.S.O. Books, Norwich, U.K., p. 5980.

LiCHTENFELS, J. R. 1977. Differences in cuticular ridges among Cooperia spp. of North American ruminants with an illustrated key to species. Proceedings of the Helminthological Society of Washington 44: 111-119.

$\longrightarrow$, AND P. A. Pilitr. 1983. Cuticular ridge patterns of Nematodirella (Nematoda: Trichostrongyloidea) of North American ruminants, with a key to species. Systematic Parasitology 5: 271-285. ,-- , AND M. B. LANCASTER. 1988. Cuticular ridge patterns of seven species of Ostertagiinae (Nematoda) parasitic in domestic ruminants. Proceedings of the Helminthological Society of Washington 55: 77-86.

Pritchard, M. H., AND G. O. W. KRUSE. 1982. The collection and preservation of animal parasites. University of Nebraska Press, Lincoln, Nebraska, $141 \mathrm{p}$.

RoDRígueZ-KABANA, R., AND P. S. KING. 1976. Tecnicas de coloracion con halogenos para monstrar detalles cuticulares de nematodos. Nematropica 6: 34-40.

VANDERBuRgh, D. J., C. A. ACKerley, D. H. LyNN, AND R. C. ANDERSON. 1987. The use of silver nitrate staining and backscattered electron imaging to visualize nematode sensory structures. Scanning Microscopy 1: $1881-1886$. 